\title{
Letter \\ Role of chlorhexidine gluconate in ventilator-associated pneumonia prevention strategies in ICU patients: where are we headed?
}

\author{
Tanmay S Panchabhai ${ }^{1}$ and Neha S Dangayach ${ }^{2}$ \\ ${ }^{1}$ Department of Medicine, University of Louisville School of Medicine, ACB, 3rd Floor, 550 S. Jackson Street, Louisville, KY 40202, USA \\ ${ }^{2}$ Department of Neurology, Case Western Reserve University School of Medicine, 11100, Euclid Avenue, Cleveland, OH 44106, USA
}

Corresponding author: Tanmay S Panchabhai, tspanchabhai@hotmail.com

Published: 27 November 2009

Critical Care 2009, 13:427 (doi:10.1186/cc8165)

This article is online at http://ccforum.com/content/13/6/427

(c) 2009 BioMed Central Ltd

See related research by Scannapieco et al., http://ccforum.com/content/13/4/R117

We read with interest the recent study by Scannapieco and colleagues [1], which concluded that twice-daily oral rinse with $0.12 \%$ chlorhexidine failed to reduce the number of potential respiratory pathogens in dental plaque, mortality, the incidence of ventilator-associated pneumonia (VAP), the length of intensive care unit (ICU) stay and the duration of mechanical ventilation in trauma ICU patients.

Trauma ICU patients are similar to mixed ICU patients with respect to risk factors for developing $\mathrm{VAP}$, unlike patients undergoing elective cardiac surgery. Use of $0.12 \%$ chlorhexidine decreases the incidence of VAP in patients undergoing elective cardiac surgery. In mixed ICU patients, chlorhexidine at concentrations less than $0.2 \%$ has consistently been shown to have no benefit [2]. A randomized trial using $2 \%$ chlorhexidine has, however, demonstrated a reduction in VAP rates in these patients [3]. A previous study showed that 12-hourly application of chlorhexidine has a sustained preventive effect on biofilm formation [4]. The lack of benefit from twice-daily oral cleansing with chlorhexidine in the present study may be due to the lower concentration of chlorhexidine.

The authors' recommendation for investigation into mechanical plaque removal with chlorhexidine would conceptually have some added benefit. Mechanical plaque removal with chlorhexidine, however, has not affected outcomes in ICU patients in two studies $[5,6]$.

We therefore suggest that further studies using oral chlorhexidine in ICU patients should be conducted using higher concentrations $(2 \%)$ to test the most appropriate frequency of use, since oral cleansing is a nursing-driven intervention and clinical trials with chlorhexidine are yet to demonstrate a mortality benefit.

\section{Competing interests}

The authors declare that they have no competing interests.

\section{References}

1. Scannapieco FA, Yu J, Raghavendran K, Vacanti A, Owens SI, Wood K, Mulotte JM: A randomized trial of chlorhexidine gluconate on oral bacterial pathogens in mechanically ventilated patients. Crit Care 2009, 13:R117.

2. Panchabhai TS, Dangayach NS, Krishnan A, Kothari VM, Karnad DR: Oropharyngeal cleansing with $0.2 \%$ chlorhexidine for prevention of nosocomial pneumonia in critically ill patients: an open label randomized trial with $0.01 \%$ potassium permanganate as control. Chest 2009, 135:1150-1156.

3. Tantipong H, Morkchareonpong C, Jaiyindee S, Thamlikitkul V: Randomized controlled trial and meta-analysis of oral decontamination with $2 \%$ chlorhexidine solution for the prevention of ventilator-associated pneumonia. Infect Control Hosp Epidemio/ 2008, 29:131-136.

4. Sekino S, Ramberg P, Uzel NG, Socranksky S, Lidhe J: The effect of a chlorhexidine regimen on de novo plaque formation. J Clin Periodontol 2004, 31:609-614.

5. Pobo A, Lisboa T, Rodriguez A, Sloe R, Margret M, Trefler S, Gomez F, Rello J: A randomized trial of dental brushing for preventing ventilator associated pneumonia. Chest 2009, 136: 433-439.

6. Munro CL, Grap MJ, Jones DJ, McClish DK, Sessler CN: Chlorhexidine, toothbrushing and preventing ventilator-associated pneumonia in critically ill adults. Am J Crit Care 2009, 18:428-437. 